\title{
Evidence That the Pseudomonas syringae pv. syringae hrp-Linked hrmA Gene Encodes an Avr-Like Protein That Acts in an hrp-Dependent Manner Within Tobacco Cells
}

\author{
James R. Alfano, Han-Suk Kim, Terrence P. Delaney, and Alan Collmer \\ Department of Plant Pathology, Cornell University, Ithaca, NY 14853, U.S.A. \\ Received 26 December 1996. Accepted 10 April 1997.
}

\begin{abstract}
A 25-kb DNA region, previously cloned from Pseudomonas syringae pv. syringae 61 in cosmid pHIR11, enables nonpathogenic bacteria such as Pseudomonas fluorescens and Escherichia coli to elicit the hypersensitive response (HR) in tobacco (Nicotiana tabacum). hrmA is located within this region, adjacent to a conserved cluster of $h r p$ genes, and is essential for nonpathogens to elicit the HR. DNA sequence analysis suggested that $h r m A$ was the second of two genes in an operon and was preceded by an open reading frame (ORF), ORF1, which is predicted to encode a 10.9-kDa protein. DNA gel blot analysis revealed that sequences hybridizing with a DNA fragment internal to $\mathrm{hrmA}$ were absent from $P$. syringae pv. syringae $\mathbf{B 7 2 8 a}$, $P$. syringae pv. tabaci 11528, and $P$. syringae pv. glycinea race $4 \mathrm{U} 1$, but present in $P$. syringae pv. tomato DC3000. A 2.4-kb BamHI-AvrII fragment carrying hrmA, ORF1, and native regulatory sequences was subcloned into broad-host-range vector pDSK519 and electroporated into $P$. syringae pv. syringae $\mathbf{B 7 2 8 a}$ and $P$. syringae pv. tabaci 11528 . The presence of the hrmA locus had no apparent effect on the ability of $P$. syringae pv. syringae $B 728$ a to cause brown spot of bean, but it caused $P$. syringae pv. tabaci 11528 to elicit the defense-associated HR rather than disease in $N$. tabacum cvs. Xanthi $\mathrm{N}$ and Xanthi $\mathrm{NC}$ and $N$. clevelandii. Furthermore, $N$. debeyii, N. glutinosa, $N$. rustica, and $N$. tabacum cvs. Petit Havana and Samsun responded with the HR to $P$. fluorescens(pHIR11). In contrast, $N$. benthamiana-P. syringae pv. tabaci interactions were unaffected by the presence of HrmA, and P. fluorescens(pHIR11) did not elicit the HR in $N$. benthamiana. The hrmA ORF was subcloned into pFLAG-CTC, which expressed HrmA with a C-terminal FLAG synthetic epitope fusion. Escherichia coli MC4100 cells carrying the functional hrp cluster and the hrmA-FLAG derivative secreted the HrpZ harpin, but not HrmA-FLAG, to the medium, as indicated by immunoblot analysis with M2 anti-FLAG and polyclonal anti-HrpZ antibodies. The hrmA ORF was also subcloned into plant expression vector pFF19 and then biolistically
\end{abstract}

Corresponding author: A. Collmer; Telephone: 607-255-7843; Fax: 607255-4471; E-mail: arc2@ cornell.edu

Nucleotide and/or amino acid sequence data are to be found at GenBank as accession no. U96179. delivered, along with pFF19G (expressing $\beta$-glucuronidase), into suspension-cultured tobacco cells. Histochemical staining $24 \mathrm{~h}$ later revealed substantial $\beta$-glucuronidase activity in cells receiving pFF19G and pFF19 but not in those receiving pFF19G and pFF19-HrmA. Thus, internal production of HrmA was deleterious to tobacco cells.

Host-specific, gram-negative, phytopathogenic bacteria typically elicit the hypersensitive response (HR) in plants with which they are incompatible. The HR is a rapid, localized necrosis that results from the apparent programmed death of plant cells in contact with incompatible pathogens and is associated with active plant defense (Klement 1982; He et al. 1993; Dietrich et al. 1994; Greenberg et al. 1994). The ability to elicit the HR or be pathogenic is controlled by hrp genes, which are probably universal among phytopathogenic bacteria in the genera Pseudomonas, Erwinia, Xanthomonas, and Ralstonia (Bonas 1994). hrp genes are now thought to be primarily involved in protein secretion, with nine of them encoding highly conserved components of a type III protein secretion system that is also present in animal-pathogenic Yersinia, Shigella, and Salmonella spp. These nine genes have been redesignated as hrc (hypersensitive response and conserved (Bogdanove et al. 1996). The hrp/hrc genes are clustered, and the 25-kb cluster from $P$. syringae pv. syringae 61, carried on cosmid pHIR11, enables nonpathogens like $P$. fluorescens and Escherichia coli to elicit the HR (Huang et al. 1988). Thus, pHIR11 encodes a minimal set of proteins required for HR elicitation.

The HrpZ harpin is an elicitor of the HR and is encoded by pHIR11 and all strains of $P$. syringae investigated (He et al. 1993; Preston et al. 1995). HrpZ, like the previously identified Erwinia amylovora HrpN harpin (Wei et al. 1992), is a glycine-rich, cysteine-lacking, heat-stable protein that is secreted in culture in an hrp-dependent manner and can elicit an HRlike necrosis in the leaves of tobacco and several other plants (He et al. 1993). The biochemical activity and biological function of HrpZ is uncertain. HrpZ has no apparent role in the host specificity of $P$. syringae (Preston et al. 1995), and deletion of hrpZ from the P. syringae pv. syringae genome only slightly reduces the ability of the bacterium to elicit the HR (Alfano et al. 1996). More puzzling are the observations 
that deletion of hrpZ from pHIR11 produces a variable HR deficiency in nonpathogens carrying the cosmid and that mutations in the pHIR11 hrmA gene abolish HR elicitation activity without affecting HrpZ synthesis or secretion (Alfano et al. 1996). hrmA (hypersensitive response modulator) is adjacent to the $h r p / h r c$ cluster in a region that appears variable in $P$. syringae and contains the avrPphE gene in $P$. syringae pv. phaseolicola (Heu and Hutcheson 1993; Mansfield et al. 1994). P. fluorescens(pHIR11) hrmA mutants do not elicit the $\mathrm{HR}$, whereas $P$. syringae pv. syringae $61 \mathrm{hrmA}$ mutants elicit a reduced HR but appear unaffected in pathogenicity (Huang et al. 1991). The hrmA coding region encodes a predicted 41$\mathrm{kDa}$ protein with no homology to known proteins, and which is regulated by the HrpL alternative sigma factor (Heu and Hutcheson 1993; Xiao and Hutcheson 1994). The location of hrmA, the limited distribution of hrmA in P. syringae pathovars, the regulation by $\mathrm{HrpL}$, and the phenotype of $\mathrm{hrmA} \mathrm{mu-}$ tations suggested that the gene encodes an Avr (avirulence)like protein that has a primary role in elicitation of the HR in tobacco leaves by nonpathogenic bacteria carrying pHIR11 (Alfano et al. 1996).

Bacterial $a v r$ genes are defined by their ability to interact with cognate plant resistance $(R)$ genes in a gene-for-gene manner to trigger a genotype-specific HR (Staskawicz et al. 1984; Keen 1990). avr genes are known to control the cultivar-specific interactions of races within several pathovars of $P$. syringae, and they may control the host specificity of $P$. syringae at the pathovar-host species level as well (Kobayshi et al. 1989). They are typically identified by screening a broad-hostrange cosmid library of donor-race DNA in a recipient race that is normally compatible on tester plant cultivars that are incompatible with the donor. Conversion of the interaction to incompatibility (avirulence) indicates the presence of an $a v r$ gene.

Our hypothesis that HrmA is functioning as an Avr protein led us to test the ability of $P$. fluorescens(pHIR11) to deliver known Avr proteins, such as AvrB. This ultimately produced evidence that AvrB must function inside plant cells following delivery by the pHIR11-encoded Hrp system (Gopalan et al. 1996). The ability of the type III protein secretion systems of Yersinia, Shigella, and Salmonella spp. to deliver virulence proteins directly into animal cells had been demonstrated previously and may be a general property of the system in both animal and plant pathogens (Rosqvist et al. 1994, 1995). Now there is evidence that three additional bacterial Avr proteins function inside plant cells (Leister et al. 1996; Scofield et al. 1996; Tang et al. 1996; Van den Ackerveken et al. 1996). Furthermore, pHIR11 has been shown to be able to deliver the signals from several avr genes that were heterologously expressed in P. fluorescens or E. coli (Gopalan et al. 1996; Pirhonen et al. 1996).

In this report we use $P$. syringae pv. syringae $\mathrm{B} 728 \mathrm{a}, P$. syringae pv. tabaci, and biolistically transformed tobacco cells to obtain further evidence that the pHIR11-encoded HrmA has Avr-like properties and that it functions within plant cells. A preliminary account of this work has been published (Collmer et al. 1996).

\section{RESULTS}

A small ORF resides between the hrp/avr box and hrmA.

An hrp/avr box, which has been reported to be responsive to transcriptional activation by the HrpL alternative sigma factor (Xiao and Hutcheson 1994), is located 518 bp upstream of the hrmA translational start (Fig. 1). Beginning 126 nucleotides downstream of the hrp/avr box, an open reading frame (ORF), ORF1, was found that predicted a protein with 96 amino acids, a molecular weight of 10,888 , an acidic pI of 5.6, and a high leucine content of $18 \%$ (Fig. 2). A potential ribosome-binding site, AAGGG, was found 10 nucleotides upstream from the ini-

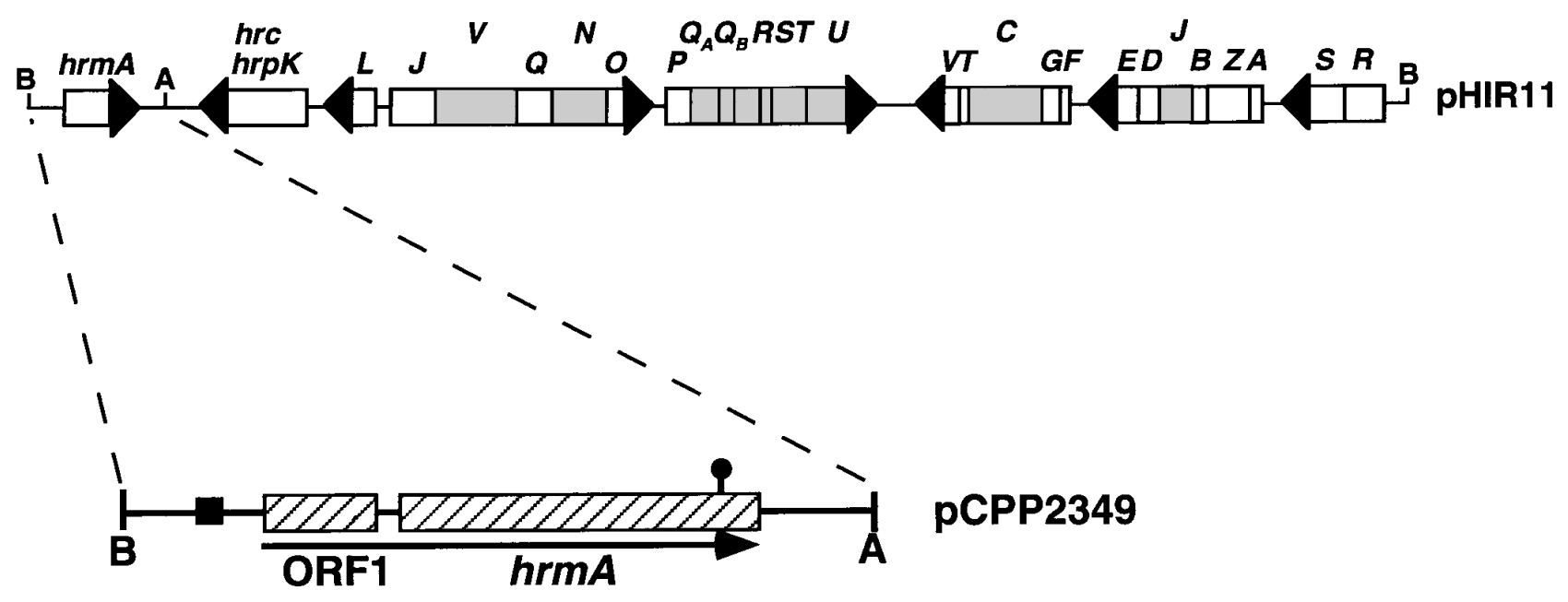

$\overline{250 \mathrm{bp}}$

Fig. 1. Map of pHIR11 detailing location of hrmA, ORF1, and a previously constructed TnPhoA insertion. Subset of hrc genes within the hrp cluster denoted with shaded boxes. ORF1 and hrmA depicted as hatched boxes. Arrow underneath ORF1 and hrmA indicates direction of transcription. Black box upstream of ORF1 represents the hrp/avr box (not drawn to scale); lollipop within the hrmA sequence shows point of insertion of the TnphoA mutation carried on pCPP2071. BamHI (B) and AvrII (A) sites are shown. 
tiation codon. Three other initiation codons are located 39, 45, and $93 \mathrm{bp}$ upstream of the putative ORF1 start, and in the same reading frame, but none of these is preceded by a consensus ribosome-binding site. The predicted ORF1 protein lacked an $\mathrm{N}$ terminal signal peptide and any likely membrane-spanning domains. A BLAST search revealed that the predicted ORF1 protein shared similarity with ExsC from $P$. aeruginosa. ORF1 was $22 \%$ identical to ExsC (Frank and Iglewski 1991), and the sequence similarity shared between the two predicted proteins was in the same region of each. The similarity was particularly high (33\% identity) in a 45 -amino-acid region in the $\mathrm{N}$-terminal portion of both proteins.

\section{Confirmation of the pCPP2071 hrmA::TnPhoA mutation.}

E. coli carrying a previously isolated pHIR11-derivative, pCPP2071, which has a TnphoA insertion mapping within hrmA, is unable to elicit an HR on tobacco (Huang et al. 1991). In view of the discovery of ORF1, we wanted to confirm that the mutation carried on pCPP2071 was within $\mathrm{hrmA}$ rather than ORF1. A 7-kb BamHI fragment containing TnphoA and adjacent $P$. syringae DNA was subcloned from pCPP2071 into pUC18. Sequencing from the end of TnphoA into flanking $P$. syringae DNA confirmed that the TnphoA insertion carried on pCPP2071 was within hrmA (Fig. 1). Therefore, the hrmA gene is required for HR elicitation by nonpathogens carrying pHIR11.

\section{DNA sequences hybridizing with $\mathrm{hrmA}$ are not present in $P$. syringae pv. tabaci.}

The hrmA locus is located on the left side of the hrp cluster on pHIR11 (Fig. 1). The hrmA ORF was amplified by polymerase chain reaction (PCR), with pCPP2324 as a template, and cloned into pFLAG-CTC. The insert was then excised by $N d e \mathrm{I} / B g I I I$ double digestion and used as a probe for DNA gel blot hybridization. P. syringae pv. tabaci 11528, P. syringae pv. glycinea race 4 U1, P. syringae pv. tomato DC3000, $P$. sy-

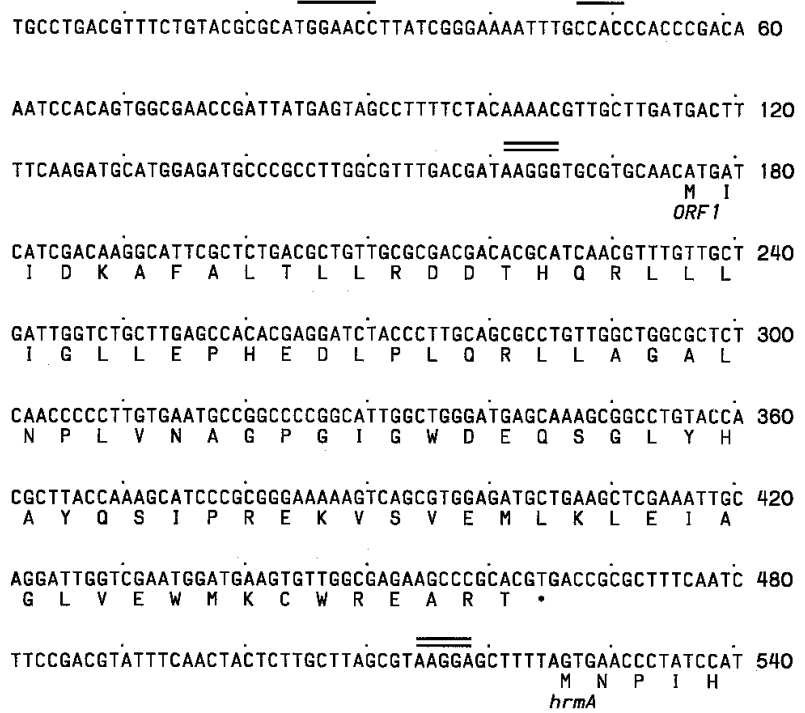

Fig. 2. DNA sequence of the ORF1 region upstream of hrmA. Putative hrp/avr box denoted with single overlines, the putative ribosomebinding sites of ORF1 and hrmA with double overlines. The GenBank accession number for ORF1 is U96179. ringae pv. syringae $\mathrm{B} 728 \mathrm{a}$, and $P$. syringae pv. syringae 61 total DNA samples were probed under conditions of moderate stringency following EcoRI digestion. No significant hybridization was observed with $P$. syringae pv. tabaci, $P$. syringae pv. glycinea, or P. syringae pv. syringae B728a DNA (Fig. 3). Hybridization was observed with $P$. syringae pv. tomato, and the hybridizing band had a different size than that in the EcoRI digest of $P$. syringae pv. syringae 61 DNA. Thus, hrmA is limited in its distribution among several experimentally important model strains of $P$. syringae, and a highly similar hrmA homolog is absent from $P$. syringae pv. tabaci 11528.

hrmA converts $P$. syringae pv. tabaci, but not $P$. syringae pv. syringae, to incompatibility on its respective host.

P. syringae pv. tabaci 11528 causes wildfire disease of tobacco, and $P$. syringae pv. syringae $\mathrm{B} 728 \mathrm{a}$ is a highly virulent agent of brown spot of bean. pCPP2349, which carries the hrmA ${ }^{+}$BamHI-AvrII fragment in the broad-host-range vector pDSK519 (Fig. 1), was constructed and electroporated into $P$. syringae pv. tabaci 11528 and $P$. syringae pv. syringae $\mathrm{B} 728 \mathrm{a}$. $P$. syringae pv. tabaci(pCPP2349) and $P$. syringae pv. tabaci(pDSK519) were infiltrated into tobacco (Nicotiana tabacum L. 'Xanthi N') leaves at five different concentrations ranging from $5 \times 10^{8}$ to $5 \times 10^{3}$ cells per ml. Leaf panels infiltrated with $P$. syringae pv. tabaci(pCPP2349) at the highest concentration displayed a typical hypersensitive collapse within $24 \mathrm{~h}$, whereas those infiltrated with lower concentrations of the bacterium failed to produce disease symptoms even after 5 days (Fig. 4). In contrast, P. syringae pv. tab-

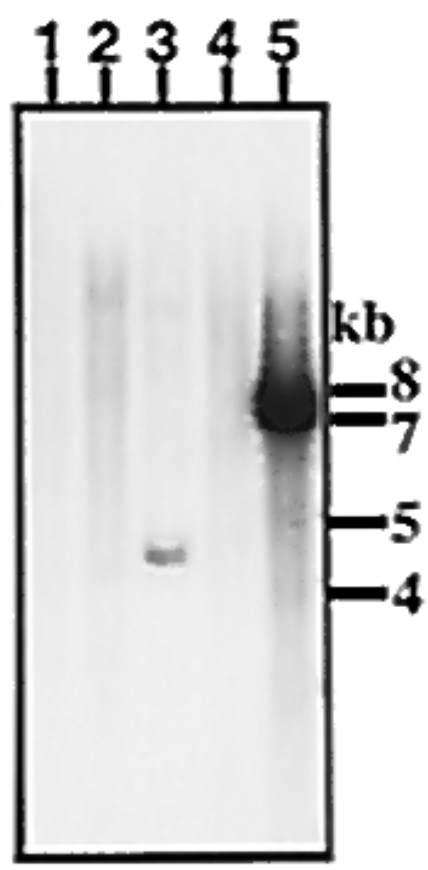

Fig. 3. DNA gel blot showing distribution of sequences hybridizing with hrmA among several experimentally important strains of Pseudomonas syringae. Total DNA from indicated strains was digested with EcoRI and resolved on a $0.8 \%$ agarose gel before electroblotting and hybridization at moderate stringency with a ${ }^{32} \mathrm{P}$-labeled hrmA probe. Lane $1, P$. syringae pv. tabaci 11528; lane 2, P. syringae pv. glycinea race $4 \mathrm{U} 1$; lane 3 , P. syringae pv. tomato DC3000; lane 4, P. syringae pv. syringae B728A; lane $5, P$. syringae pv. syringae 61. 
aci(pDSK519) elicited no visible response $24 \mathrm{~h}$ after inoculation, but at several inoculum levels it produced disease symptoms within 5 days (Fig. 4). Furthermore, the growth of $P$. syringae pv. tabaci(pDSK519) was substantially higher than that of $P$. syringae pv. tabaci(pCPP2349) at all inoculum levels (data not shown). P. syringae pv. syringae(pCPP2349) and $P$. syringae pv. syringae(pDSK519) were similarly infiltrated into bean (Phaseolus vulgaris L. 'Eagle') leaves at $5 \times$ $10^{8}, 5 \times 10^{6}, 5 \times 10^{5}$, and $5 \times 10^{4}$ cells per ml. Both strains were identical in failing to elicit any visible response in the first $24 \mathrm{~h}$ at any concentration and in producing a slowly spreading lesion at all but the lowest concentration (data not shown). Thus, hrmA converts the interaction of $P$. syringae pv. tabaci and tobacco to incompatibility, but it has no apparent effect on the interaction of $P$. syringae pv. syringae B728a with bean cv. Eagle.

The reactions of $h r m A^{+}$bacteria with other Nicotiana spp. and $N$. tabacum cultivars were tested by infiltrating leaves with $P$. fluorescens(pHIR11) at $5 \times 10^{8}$ cells per $\mathrm{ml}$ and $P$. syringae pv. tabaci(pDSK519) and $P$. syringae pv. tabaci(pCPP2349) at both $1 \times 10^{8}$ and $1 \times 10^{6}$ cells per ml. Plant reactions were then scored at 1 and 5 days. N. tabacum cv. Xanthi NC and N. clevelandii responded, as did N. tabacum L. cv. Xanthi N (data not shown). That is, in each of these plants, $P$. fluorescens(pHIR11) elicited an HR at $5 \times 10^{8}$ cells per ml, and $P$. syringae pv. tabaci at $1 \times 10^{6}$ cells per $\mathrm{ml}$ caused disease after several days but failed to produce disease symptoms when carrying pCPP2349. N. debeyi, $N$. glutinosa, $N$. rustica, and $N$. tabacum cvs. Petit Havana and Samsun were tested only with $P$. fluorescens(pHIR11) at $5 \times 10^{8}$ cells per ml, but all responded with a typical HR. In contrast, $N$. benthamiana failed to respond with the HR when infiltrated with any of the bacteria carrying $h r m A$, and it produced disease symptoms when inoculated with $P$. syringae pv. tabaci, regardless of the presence of $h r m A$. Thus, the $R$ gene proposed to interact with hrmA appears to be present in all cultivars of $N$. tabacum tested and in most Nicotiana spp.

\section{HrmA-FLAG is not secreted in culture under conditions in which $\mathrm{HrpZ}$ is secreted.}

To determine if HrmA, like HrpZ, can be secreted in culture by E. coli MC4100 cells carrying pHIR11, we constructed pCPP2352, a derivative of hrmA that produced full-length HrmA carrying a C-terminal fusion with the FLAG synthetic epitope (Hopp et al. 1988). E. coli MC4100 cells carrying both pHIR11 and pCPP2352 were grown in hrp-derepressing minimal medium to late-log phase, and then cells were separated from the medium by centrifugation. Proteins in the cell and supernatant fractions were resolved by sodium dodecyl sulfate-polyacrylamide gel electrophoresis (SDS-PAGE) and subjected to immunoblot analysis with M2 anti-FLAG and polyclonal anti-HrpZ antibodies. HrpZ was detected in the culture supernatant, whereas HrmA-FLAG was not, despite the presence of a large cell-bound pool (Fig. 5). pCPP2324
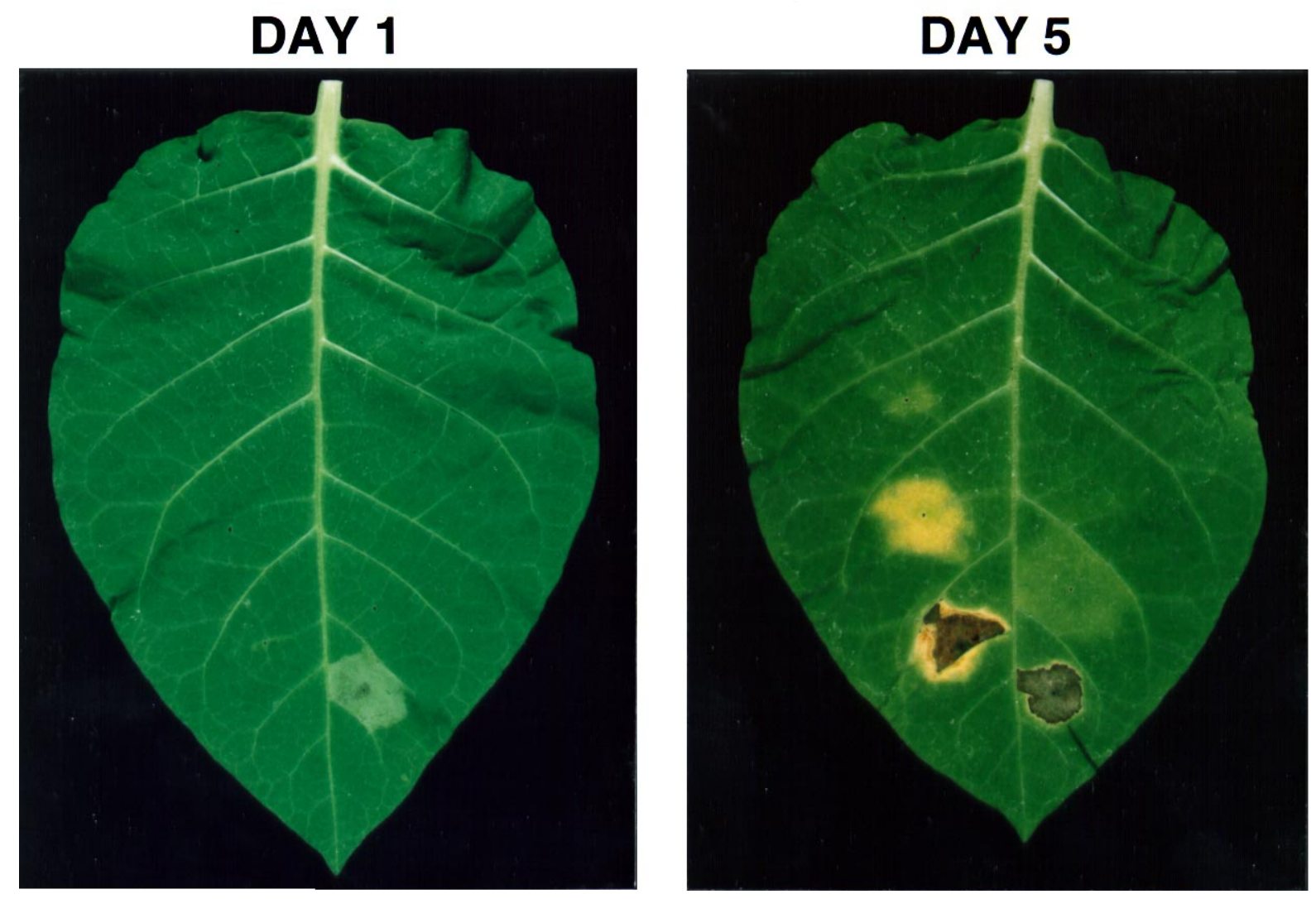

Fig. 4. Responses of tobacco leaves at 1 and 5 days post-infiltration to different levels of inoculum of $P$. syringae pv. tabaci 11528 either lacking or heterologously expressing the $h r m A$ region carried on pCPP2349. On both leaves, panels on the left and right sides were inoculated with vector control and hrmA $A^{+}$strains, respectively. Beginning with the lowest panel on each leaf half and progressing upward, the levels of inoculum were $5 \times 10^{8}, 5 \times 10^{6}, 5 \times$ $10^{4}$, and $5 \times 10^{3}$ cells per $\mathrm{ml}$. 
$\left(\mathrm{HrmA}^{+}\right)$and $\mathrm{pCPP} 2352\left(\mathrm{HrmA}-\mathrm{FLAG}^{+}\right)$restored the HR phenotype to $P$. syringae pv. syringae 61-2071 equally well (data not shown).

\section{Transient expression of $\mathrm{hrmA}$ in tobacco cells leads to apparent cell death.}

A site of HrmA action in the interior of tobacco cells was suggested by the observations that HrmA was not released to the medium of bacteria carrying pHIR 11 and had no apparent effect when infiltrated into tobacco leaf intercellular spaces, even though it was absolutely required for HR elicitation (data not shown). To determine whether expression of hrmA within tobacco cells was lethal, a transient expression protocol similar to that used by Mindrinos et al. (1994) was employed. In this technique, plant cells are doubly transformed with vectors expressing $\beta$-glucuronidase (GUS) and a test gene; if the test gene is lethal, GUS activity is reduced or eliminated. The hrmA ORF was subcloned into the plant expression vector pFF19 and biolistically delivered, along with the $\mathrm{GUS}^{+}$plasmid pFF19G, into suspension-cultured tobacco cells. After incubation for $24 \mathrm{~h}$, the tobacco cells were histochemically stained for GUS activity. Filters covered with tobacco cells co-bombarded with pFF19G and pFF19 showed extensive GUS activity, whereas those co-bombarded with pFF19G and

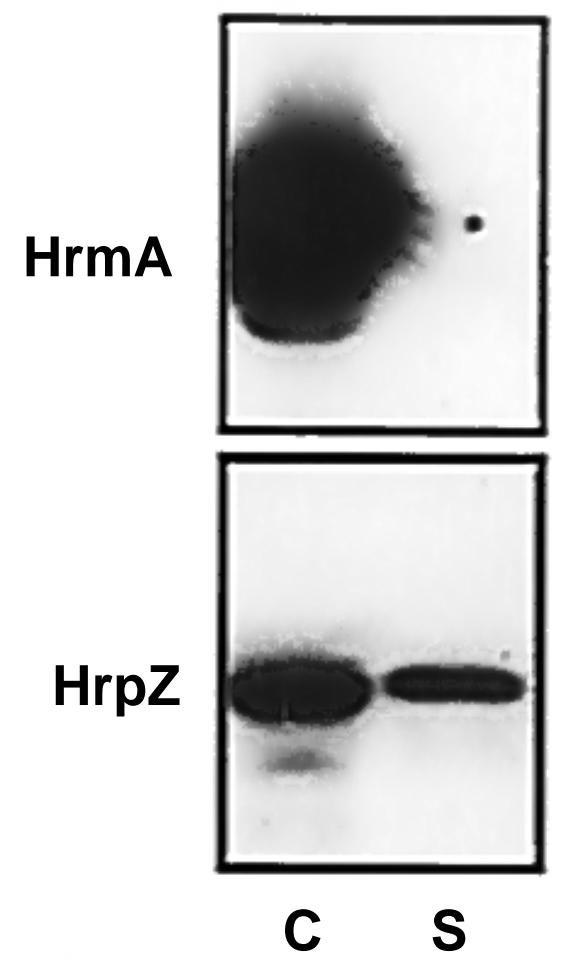

Fig. 5. Immunoblot analysis of the distribution of HrpZ and HrmAFLAG between cell-bound and culture fluid fractions of Escherichia coli MC4100 cells carrying pHIR11 and pCPP2352. Bacterial cells were removed from a mid-log phase culture by centrifugation, and then the presence of HrmA-FLAG and HrpZ in each fraction was determined by sodium dodecyl sulfate-polyacrylamide gel electrophoresis followed by immunoblot analysis with M2 anti-FLAG monoclonal antibodies and anti-HrpZ polyclonal antibodies. Supernatant fractions were concentrated 20-fold and cell fractions were concentrated fivefold relative to initial culture volumes before electrophoresis.
pFF19-HrmA showed a 30-fold reduction in the number of blue spots (Fig. 6). This indicated that the expression of hrmA within tobacco cells was deleterious.

\section{DISCUSSION}

We have provided further evidence that $P$. syringae pv. syringae $61 \mathrm{HrmA}$ has properties of an Avr protein interacting with an unidentified $R$ gene that is present in nonhost tobacco but not in host bean. Introduction of the hrmA gene into $P$. syringae pv. tabaci 11528 and $P$. syringae pv. syringae $\mathrm{B} 728 \mathrm{a}$, two strains we have shown to naturally lack the gene, converts only the former to incompatibility with its host. Such an ability to confer avirulence is part of the original operational definition of avr genes (Staskawicz et al. 1984; Keen 1990). HrmA has two additional properties that are consistent with an Avr-like function, as predicted by the hypothesis that some Avr proteins act within plant cells following contactdependent delivery via the Hrp secretion system (Alfano and Collmer 1996; Gopalan et al. 1996). First, bacterial elicitation of a HrmA-dependent HR requires a functional Hrp secretion system, even though HrmA was shown not to be secreted in culture. Second, HrmA has an apparently lethal effect on tobacco cells but only when produced in the interior of these cells. Several aspects of these observations and the hrmA locus are discussed below.

hrmA appears to be the second of two genes in the hrmA operon. The upstream ORF1 uses typically preferred $P$. syringae pv. syringae codons to encode a predicted $10.9-\mathrm{kDa}$ protein with weak similarity to $P$. aeruginosa ExsC. ExsC is the gene product of $\operatorname{exs} C$, which is the first gene in a three-gene operon known as the trans-regulatory locus for exoenzyme $S$ synthesis because it is required for synthesis of the secreted ExoS protein (Frank and Iglewski 1991). Interestingly, the other two genes of this operon, $\operatorname{exs} B$ and $\operatorname{exs} A$, have homologs involved in the regulation and secretion of the type IIIsecreted Yop virulence proteins of Yersinia spp. ExsC has an apparent role in the translation or stability of ExoS (Goranson et al. 1997). Recently, it has been shown that the amino terminal portion of ExoS is similar to the type III-secreted YopE protein of Yersinia (Yahr et al. 1995; Kaniga et al. 1996), and that ExoS is secreted by a type III pathway (Yahr et al. 1996). Therefore, even though the sequence similarity between the predicted proteins encoded by ORF1 and ExsC is weak, it is

\section{pFF19G/pFF19}

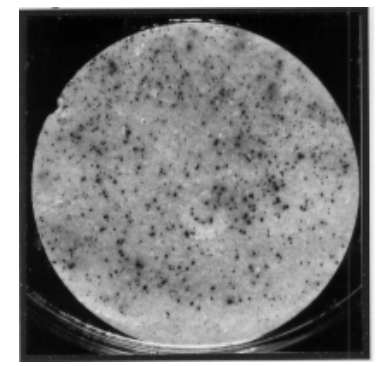

\section{pFF19G/pFF19-HRMA}

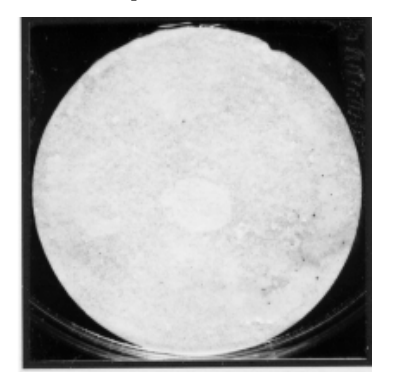

Fig. 6. Transient expression assay for deleterious effects of hrmA expression within tobacco cells. Tobacco suspension-cultured cells were collected on Whatman \#4 filters and biolistically co-bombarded with pFF19G and either pFF19 or pFF19-HrmA, as indicated. Cells on filters were incubated for $24 \mathrm{~h}$, histochemically stained for $\beta$-glucuronidase activity, and then photographed. 
likely that the similarity is significant and that ORF1 codes for a protein that has some role in HrmA function. One attractive possibility that we are currently testing is that ORF1 encodes a chaperone for HrmA secretion, similar to the chaperones that are present in the type III secretion systems of animal pathogens and that are required for secretion of specific virulence proteins (Wattiau et al. 1996). By confirming that the TnPhoA insertion in pCPP2071 was in $h r m A$, we confirmed that $h r m A$ is required for bacteria carrying pHIR11 to elicit the HR. Functionally nonpolar mutations are now required to determine if ORF1 is also required. We converted $P$. syringae pv. tabaci to avirulence by using a clone carrying the complete locus, including ORF1, hrmA, and upstream regulatory sequences. Consequently, it is unclear whether hrmA is sufficient to convert $P$. syringae pv. tabaci to avirulence, although the $h r m A$ coding region alone is sufficient to have a deleterious effect in tobacco cells.

As previously reported (Heu and Hutcheson 1993), hrmA is present in relatively few strains of $P$. syringae. Here we tested for its presence specifically in several experimentally important model strains. As predicted, hrmA is lacking in the tobacco pathogen $P$. syringae pv. tabaci 11528 . It is also lacking in $P$. syringae pv. syringae $\mathrm{B} 728 \mathrm{a}$, a model for the study of epiphytic fitness factors, and $P$. syringae pv. glycinea race 4, a model for the study of $a v r$-mediated race-cultivar interactions. However, sequences hybridizing with $h r m A$ were found in $P$. syringae pv. tomato DC3000, an extensively studied strain that is pathogenic on both Arabidopsis and tomato. We are now cloning the hybridizing locus from DC3000 to learn whether it is linked with an ORF1 homolog, has the same effects as the $P$. syringae pv. syringae $61 \mathrm{hrmA}$ when expressed in $P$. syringae pv. tabaci or tobacco cells, and contributes to virulence.

Our data suggest that the $R$ gene proposed to interact with hrmA is present in many Nicotiana spp. but lacking in legumes. This is consistent with previous observations that $P$. syringae pv. syringae 61 is a weak pathogen of legumes such as bean and pea, but is a strong elicitor of the HR in tobacco, and that nonpathogenic bacteria carrying pHIR11 elicit the HR in tobacco but not in legumes (Huang et al. 1988). We have further explored this relationship by demonstrating with bean and several Nicotiana spp. and N. tabacum cultivars that P. fluorescens(pHIR11) elicits the HR only in plants in which heterologous hrmA expression can convert a virulent $P$. syringae strain to avirulence. Thus, the reason that the hrp cluster carried on pHIR11 is the only one from $P$. syringae reported to enable nonpathogens to elicit the HR is likely due to two factors. The DNA cloned contains a complete set of conserved hrp secretion and positive regulatory genes, and a linked variable region happens to contain an $a v r$ gene that interacts with an $R$ gene in tobacco, the plant most commonly tested for bacterial HR elicitation activity. This model is further supported by the observation that the range of plants in which bacteria carrying pHIR11 elicit the HR can be extended by heterologous expression of appropriate $a v r$ genes (e.g., $a v r B$; Gopalan et al. 1996; Pirhonen et al. 1996).

hrmA shares some properties with $a v r E$ and others with $a v r B$. Kobayashi et al. (1989) originally isolated $a v r E$ from $P$. syringae pv. tomato on the basis of its ability to convert $P$. syringae pv. glycinea race 4 (virulent on a wide range of tester soybean cultivars) to avirulence on several cultivars. Further analysis revealed that $a v r E$ appears to interact with an unknown $R$ gene present in all soybean cultivars tested, occurs in a complex locus, is part of the hrp regulon, and is linked to the $h r p$ cluster (Lorang and Keen 1995). These properties are similar to those of hrmA. The similarities of hrmA and $P$. syringae pv. glycinea avrB are based on a rather different analysis of avr gene function. Both are required for $P$. fluorescens(pHIR11) or normally compatible $P$. syringae strains to elicit the HR in certain plants (Huang et al. 1991; Gopalan et al. 1996; Pirhonen et al. 1996). Both require conserved Hrp secretion system components, such as HrcC (Alfano et al. 1996; Gopalan et al. 1996; Pirhonen et al. 1996), for their action, yet neither is secreted in culture under conditions in which HrpZ is secreted. Neither has any apparent effect when infiltrated into the intercellular spaces of leaves carrying the cognate resistance genes, but both elicit apparent cell death when heterologously expressed in the interior of such plant cells (Gopalan et al. 1996). Demonstration of the $R$ genedependent lethal activity of AvrB in plant cells was aided by the existence of isogenic Arabidopsis lines that are differential for the RPM1 R gene (Gopalan et al. 1996). Unfortunately, the putative $R$ gene interacting with hrmA appears to be present in all of the cultivars of $N$. tabacum that we tested, so we could not explore the effect of transient hrmA expression in cells from a cultivar that does not respond hypersensitively to bacteria carrying $h r m A$.

The hrmA gene was originally named because of its weak HR phenotype in $P$. syringae pv. syringae 61 (Huang et al. 1991). As we have described above, hrmA is avr-like, but without a demonstrable $R$ gene interaction. Therefore, its classification as an $a v r$ gene is uncertain. Indeed, our concept of the role of Avr proteins in P. syringae pathogenesis is being transformed by the accumulating evidence that these factors have a primary role in virulence and that a key property of several of them is that they act within plant cells following secretion by the Hrp pathway (Alfano and Collmer 1996). Thus, rather than considering HrmA as an "Avr-like" protein, it may be more useful to think of both HrmA and many Avr proteins (e.g., AvrB, AvrPto, AvrRpt2, and AvrBs3) as members of a larger class of "Hops" (Hrp-dependent outer proteins). This designation is analogous to the Yops (Yersinia outer proteins) designation for the proteins secreted by the prototypical Yersinia ysc-encoded type III secretion system, but is broadened here to "Hrp-dependent" rather than "Pseudomonas" to reflect the current, conveniently broad usage of "Hrp" and "Avr" for all plant pathogens. As with the Yops, $P$. syringae proteins in the Hop class may be targeted to the milieu or to the interior of host cells. Thus, it appears that the pHIR11 Hrp system, while sufficient to deliver Hop proteins targeted to the host cell, has no intrinsic ability to elicit the HR in the absence of such proteins. That is, as with the Yops, the Hops that are targeted to the interior of host cells are the key effectors of the interaction.

\section{MATERIALS AND METHODS}

\section{Bacterial strains, plasmids, and media.}

Bacterial strains and plasmids are listed in Table 1. E. coli strains were routinely grown in LM (Hanahan 1983) at $37^{\circ} \mathrm{C}$, but MC4100 cultures carrying pHIR11 were grown at $30^{\circ} \mathrm{C}$ in King's B broth (King et al. 1954). To express the hrp genes in 
culture, bacteria were grown in the hrp-derepressing medium of Huynh et al. (1989). P. syringae strains were grown in King's B medium at $30^{\circ} \mathrm{C}$. Inoculum for virulence assays was obtained by washing cells off of overnight King's B plates with $5 \mathrm{mM} 2-[\mathrm{N}$ morpholino]ethanesulfonic acid and harvesting them by centrifugation at $3,000 \times g$ for $10 \mathrm{~min}$, followed by resuspension in the same buffer. Antibiotics were used at the following concentrations $(\mu \mathrm{g} / \mathrm{ml})$ : ampicillin, 100 ; tetracycline, 20; kanamycin, 50; nalidixic acid, 20; rifampicin, 50.

\section{Plant materials.}

$N$. benthamiana, $N$. clevelandii, $N$. debeyi, $N$. glutinosa, $N$. rustica, N. tabacum cv. Xanthi N, N. tabacum cv. Xanthi NC, N. tabacum cv. Petit Havana, N. tabacum cv. Samsun, and bean (Phaseolus vulgaris cv. Eagle) were grown in a greenhouse with supplemental metal halide lamp illumination and a photoperiod of $16 \mathrm{~h}$. Bacteria were infiltrated into tobacco leaves through a small dissecting-needle wound, with syringes lacking needles. To inoculate bean, leaves were similarly infiltrated, but through stomata without prior wounding. The

Table 1. Bacterial strains and plasmids used in this work

\begin{tabular}{|c|c|c|}
\hline Strain or plasmid & $\begin{array}{l}\text { Relevant } \\
\text { characteristics }\end{array}$ & Source or reference \\
\hline \multicolumn{3}{|l|}{ Escherichia coli } \\
\hline DH5 $\alpha$ & $\begin{array}{l}\text { hsdR17 recA1 endA1 } \\
\text { relA1 } \mathrm{Nal}^{\mathrm{r}}\end{array}$ & $\begin{array}{l}\text { Life Technologies } \\
\text { (Gaithersburg, MD) }\end{array}$ \\
\hline MC4100 & $\begin{array}{l}\mathrm{F}-\Delta(\text { lac }) U 169 \\
\text { araD136 relA rpsL } \\
\text { thi } \mathrm{Sm}^{\mathrm{r}}\end{array}$ & $\begin{array}{l}\text { Oliver and Beckwith } \\
1981\end{array}$ \\
\hline \multicolumn{3}{|l|}{ Pseudomonas syringae } \\
\hline pv. syringae 61 & Wild type, $\mathrm{Nal}^{\mathrm{r}}$ & Huang et al. 1988 \\
\hline pv. syringae 61-2071 & hrmA::TnPhoA & Huang et al. 1991 \\
\hline pv. syringae $\mathrm{B} 728 \mathrm{a}$ & Wild type, Rif $^{\mathrm{r}}$ & Willis et al. 1988 \\
\hline pv. tabaci 11528 & Wild type, Rif $^{\mathrm{r}}$ & $\begin{array}{l}\text { American Type Cul- } \\
\text { ture Collection }\end{array}$ \\
\hline pv.tomato DC3000 & Wild type, Rif $^{r}$ & Cuppels 1986 \\
\hline pv. glycinea race $4 \mathrm{U} 1$ & Wild type & N. T. Keen \\
\hline \multicolumn{3}{|l|}{ Plasmids } \\
\hline pUC18 & Cloning vector, $\mathrm{Ap}^{\mathrm{r}}$ & $\begin{array}{l}\text { Yanisch-Perron et al. } \\
1985\end{array}$ \\
\hline pBluescript II KS ${ }^{-}$ & Cloning vector, $\mathrm{Ap}^{\mathrm{r}}$ & $\begin{array}{l}\text { Stratagene (La Jolla, } \\
\text { CA) }\end{array}$ \\
\hline pDSK519 & IncQ vector, $\mathrm{Km}^{\mathrm{r}}$ & Keen et al. 1988 \\
\hline pCPР2324 & $\begin{array}{l}\text { pBluescript II } \mathrm{KS}^{-} \\
\text {carrying } 2.4-\mathrm{kb} \\
\text { BamHI-AvrII } \mathrm{hrmA}^{+} \\
\text {fragment }\end{array}$ & This work \\
\hline pCPР2349 & $\begin{array}{l}\text { pDSK519 carrying } \\
\text { 2.4-kb BamHI-AvrII } \\
\text { hrmA } A^{+} \text {fragment }\end{array}$ & This work \\
\hline pFLAG-CTC & $\begin{array}{l}\text { FLAG expression } \\
\text { vector, } A^{\mathrm{r}}\end{array}$ & $\begin{array}{l}\text { IBI/Kodak (New } \\
\text { Haven, CT) }\end{array}$ \\
\hline pCPP2352 & $\begin{array}{l}\text { pFLAG-CTC carry- } \\
\text { ing hrmA ORF in } \\
\text { NdeI-BglII sites }\end{array}$ & This work \\
\hline pCPP2356 & $\begin{array}{l}\text { pUC18 carrying } \\
\text { TnphoA and flank- } \\
\text { ing DNA from } \\
\text { pCPP2071 }\end{array}$ & This work \\
\hline pFF19 & $\begin{array}{l}\text { Plant expression } \\
\text { vector }\end{array}$ & $\begin{array}{l}\text { Timmermans et al. } \\
1990\end{array}$ \\
\hline pFF19G & pFF19 carrying uidA & $\begin{array}{l}\text { Timmermans et al. } \\
1990\end{array}$ \\
\hline pFF19-HrmA & $\begin{array}{l}\text { pFF19 carrying } \\
\text { hrmAORF }\end{array}$ & This work \\
\hline
\end{tabular}

NT1 line of $N$. tabacum suspension-cultured cells were grown in NT1 medium (Paszty and Lurquin 1987) at $150 \mathrm{rpm}$ (shaker model G2, New Brunswick Scientific, Edison, NJ) and at $24^{\circ} \mathrm{C}$. Four-day-old cells, in early-log phase, were used for biolistic experiments.

\section{DNA manipulations.}

Plasmid DNA manipulations were done by standard procedures (Sambrook et al. 1989). The procedures used have been described previously for the isolation of chromosomal DNA from P. syringae (Silhavy et al. 1984), PCR amplification of DNA for subcloning (Alfano et al. 1996), and DNA gel blot hybridizations with Immobilon-N membrane (Millipore, Bedford, MA). Hybridization and washing were done at $50^{\circ} \mathrm{C}$ in $1 \times \mathrm{SSC}(1 \times \mathrm{SSC}$ is $0.15 \mathrm{M} \mathrm{NaCl}$ plus $0.015 \mathrm{M}$ sodium citrate) with $0.2 \%$ SDS. Both strands of a 700 -bp DNA region upstream of hrmA were sequenced with synthetic primers and the ABI 373A sequencer (Applied Biosystems, Foster City, CA) at the Cornell Biotechnology Center. DNA sequences were analyzed with the DNAStar software package (DNAstar, Madison, WI). pDSK519 and pCPP2349 were introduced into $P$. syringae strains by electroporation as described.

\section{Plasmid constructions.}

The 2.4-kb BamHI-AvrII $h r m A^{+}$fragment from pHIR11 was first cloned into pBluescript II $\mathrm{KS}^{-}$to produce pCPP2324. This plasmid was used as a template for DNA sequencing. The pCPP2324 insert was re-cloned as a BamHI-SstI fragment into pDSK519 to produce pCPP2349. To clone hrmA into pFLAG-CTC, the ORF was amplified from pCPP2324 by PCR by standard procedures (Innis et al. 1990) with the following primers that introduced $N d e \mathrm{I}$ and $B g l \mathrm{II}$ restriction sites at the $5^{\prime}$ and $3^{\prime}$ ends of $h r m A$, respectively: 5'-ATGACATAT GAACCCTATCCATGCA $-3^{\prime}$ and 5'-ATGAAGATCTGTTTC GCGCCCTGAGCGC-3'. Similarly, the following primers, which introduced Bam HI and PstI restriction sites at the 5' and $3^{\prime}$ ends of the amplified hrmA product, respectively, were used to amplify and clone hrmA into pFF19: 5'-ATGAGGAT CCGTGAACCCTATCCATGCA-3' and $5^{\prime}$-ATG ACTGCAGT CAGTTTCGCGCCCTGAG-3'.

Immunoblot assays for HrmA and HrpZ in culture fluids.

E. coli MC4100(pCPP2352) was grown overnight in King's $\mathrm{B}$ broth and then diluted to an $\mathrm{OD}_{600}$ of $0.6 \mathrm{in} 10 \mathrm{ml}$ of $\mathrm{hrp}$ derepressing minimal medium (Huynh et al. 1989). After $18 \mathrm{~h}$ of further incubation, bacterial cells were separated from culture fluids by centrifugation at $3,000 \times g$ for $10 \mathrm{~min}$ and resuspended in $2 \mathrm{ml}$ of fresh medium. Culture supernatants containing $1 \mathrm{mM}$ phenylmethylsulfonyl fluoride were passed through a $0.2-\mu \mathrm{m}$ filter and concentrated 20 -fold by ultrafiltration with Centriprep concentrators (Amicon, Beverly, MA). SDS-PAGE was done by standard procedures (Sambrook et al. 1989). For immunoblot analysis, separated proteins were transferred to Immobilin-P (Millipore). HrpZ was recognized with rabbit polyclonal antibodies raised to $\mathrm{HrpZ}$ and then followed with goat-anti-rabbit $\operatorname{IgG}$ alkaline phosphate conjugate as secondary antibody. Commercially available M2 antiFLAG monoclonal antibodies (IBI/Kodak, New Haven, CT) and goat-anti-mouse IgG alkaline phosphate conjugate were used to detect HrmA-FLAG. Both secondary antibody conjugates were purchased from Sigma (St. Louis, MO) and used at 
their recommended dilutions. Membrane-bound secondary antibodies were visualized by chemiluminescence with the Western Light chemiluminescent detection system (Tropix, Bedford, MA).

\section{Biolistics.}

Particle bombardment procedures were done as described (Russell et al. 1991) with some modifications. Briefly, 4-dayold tobacco suspension-cultured cells grown in NT1 medium were diluted so the fresh weight of tobacco cells was about $100 \mathrm{mg} / \mathrm{ml}$. Four milliliters of diluted suspension-cultured cells was collected by filtration on $5.5-\mathrm{cm}$ Whatman \#4 filter paper. Tobacco cells on filter paper supports were transferred to NT1 plates. Biolistic transformation of suspension-cultured tobacco cells was done with the PDS-1000/He apparatus (BioRad, Hercules, CA) and 1,300-lb/in ${ }^{2}$ rupture disks. For each co-bombardment, $0.5 \mathrm{mg}$ of tungsten particles (Sylvania GTE Products, Towanda, PA) was coated with $1.0 \mu \mathrm{g}$ of pFF19G and $0.5 \mu \mathrm{g}$ of either pFF19 or pFF19-HrmA. After bombardment, tobacco cells were incubated at $24^{\circ} \mathrm{C}$ for $24 \mathrm{~h}$, then cells on filter paper supports were transferred to clean petri plates and histochemically stained for $24 \mathrm{~h}$ with 5-bromo-4-chloro-3indolyl glucuronide (X-gluc) as a substrate (Jefferson et al. 1987).

\section{ACKNOWLEDGMENTS}

We thank Karen Kindle and Rody Spivey for invaluable assistance with tobacco cell suspension cultures and biolistics and Kent Loeffler for photography. This work was supported by NSF grant MCB 9631530.

\section{LITERATURE CITED}

Alfano, J. R., Bauer, D. W., Milos, T. M., and Collmer, A. 1996. Analysis of the role of the Pseudomonas syringae pv. syringae HrpZ harpin in elicitation of the hypersensitive response in tobacco using functionally nonpolar deletion mutations, truncated HrpZ fragments, and hrmA mutations. Mol. Microbiol. 19:715-728.

Alfano, J. R., and Collmer, A. 1996. Bacterial pathogens in plants: Life up against the wall. Plant Cell 8:1683-1698.

Bogdanove, A. J., Beer, S. V., Bonas, U., Boucher, C. A., Collmer, A., Coplin, D. L., Cornelis, G. R., Huang, H.-C., Hutcheson, S. W., Panopoulos, N. J., and Van Gijsegem, F. 1996. Unified nomenclature for broadly conserved hrp genes of phytopathogenic bacteria. Mol. Microbiol. 20:681-683.

Bonas, U. 1994. hrp genes of phytopathogenic bacteria. Pages 79-98 in: Current Topics in Microbiology and Immunology, Vol. 192: Bacterial Pathogenesis of Plants and Animals - Molecular and Cellular Mechanisms. J. L. Dangl, ed. Springer-Verlag, Berlin.

Collmer, A., Alfano, J. R., Bauer, D. W., Preston, G. M., Loniello, A. O., Conlin, A., Ham, J. H., Huang, H.-C., Gopalan, S., and He, S. Y. 1996. Secreted proteins, secretion pathways, and the plant pathogenicity of Erwinia chrysanthemi and Pseudomonas syringae. Pages 159-164 in: Biology of Plant-Microbe Interactions. G. Stacey, B. Mullin, and P. M. Gresshoff, eds. Int. Soc. Mol. Plant-Microbe Interact., St. Paul, MN.

Cuppels, D. A. 1986. Generation and characterization of $\operatorname{Tn} 5$ insertion mutations in Pseudomonas syringae pv. tomato. Appl. Environ. Microbiol. 51:323-327.

Dietrich, R. A., Delaney, T. P., Uknes, S. J., Ward, E. R., Ryals, J. A., and Dangl, J. L. 1994. Arabidopsis mutants simulating disease resistance response. Cell 77:565-577.

Frank, D. W., and Iglewski, B. H. 1991. Cloning and sequence analysis of a trans-regulatory locus required for exoenzyme $\mathrm{S}$ synthesis in Pseudomonas aeruginosa. J. Bacteriol. 173:6460-6468.

Gopalan, S., Bauer, D. W., Alfano, J. R., Loniello, A. O., He, S. Y., and Collmer, A. 1996. Expression of the Pseudomonas syringae avirulence protein AvrB in plant cells alleviates its dependence on the hy- persensitive response and pathogenicity (Hrp) secretion system in eliciting genotype-specific hypersensitive cell death. Plant Cell 8:1095-1105.

Goranson, J., Hovey, A. K., and Frank, D. W. 1997. Functional analysis of exs $C$ and $\operatorname{exs} B$ in regulation of exoenzyme $\mathrm{S}$ production by Pseudomonas aeruginosa. J. Bacteriol. 179:1646-1654.

Greenberg, J. T., Guo, A., Klessig, D. F., and Ausubel, F. M. 1994. Programmed cell death in plants: A pathogen-triggered response activated coordinately with multiple defense functions. Cell 77:551-563.

Hanahan, D. 1983. Studies on transformation of Escherichia coli with plasmids. J. Mol. Biol. 166:557- 580.

He, S. Y., Huang, H.-C., and Collmer, A. 1993. Pseudomonas syringae pv. syringae harpin ${ }_{\mathrm{Pss}}$ : A protein that is secreted via the Hrp pathway and elicits the hypersensitive response in plants. Cell 73:1255-1266.

Heu, S., and Hutcheson, S. W. 1993. Nucleotide sequence and properties of the hrmA locus associated with the Pseudomonas syringae pv. syringae 61 hrp gene cluster. Mol. Plant-Microbe Interact. 6:553-564.

Hopp, T. P., Prickett, K. S., Price, V., Libby, R. T., March, C. J., Cerretti, P., Urdal, D. L., and Conlon, P. J. 1988. A short polypeptide marker sequence useful for recombinant protein identification and purification. Bio/Technology 6:1205-1210.

Huang, H.-C., Hutcheson, S. W., and Collmer, A. 1991. Characterization of the hrp cluster from Pseudomonas syringae pv. syringae 61 and TnphoA tagging of genes encoding exported or membrane-spanning Hrp proteins. Mol. Plant-Microbe Interact. 4:469-476.

Huang, H.-C., Lin, R.-W., Chang, C.-J., Collmer, A., and Deng, W.-L. 1995. The complete hrp gene cluster of Pseudomonas syringae pv. syringae 61 includes two blocks of genes required for harpin ${ }_{\mathrm{Pss}}$ secretion that are arranged colinearly with Yersinia ysc homologs. Mol. Plant-Microbe Interact. 8:733-746.

Huang, H.-C., Schuurink, R., Denny, T. P., Atkinson, M. M., Baker, C. J., Yucel, I., Hutcheson, S. W., and Collmer, A. 1988. Molecular cloning of a Pseudomonas syringae pv. syringae gene cluster that enables Pseudomonas fluorescens to elicit the hypersensitive response in tobacco. J. Bacteriol. 170:4748-4756.

Huynh, T. V., Dahlbeck, D., and Staskawicz, B. J. 1989. Bacterial blight of soybean: Regulation of a pathogen gene determining host cultivar specificity. Science 245:1374-1377.

Innis, M. A., Gelfand, D. H., Sninsky, J. J., and White, T. J. 1990. PCR Protocols. Academic Press, San Diego, CA

Jefferson, R. A., Kavanagh, T. A., and Bevan, M. W. 1987. GUS fusions: $\beta$-glucuronidase as a sensitive and versatile gene fusion marker in higher plants. EMBO J. 6:3901-3907.

Kaniga, K., Uralil, J., Bliska, J. B., and Galan, J. E. 1996. A secreted protein tyrosine phosphatase with modular effector domains in the bacterial pathogen Salmonella typhimurium. Mol. Microbiol. 21:633641

Keen, N. T. 1990. Gene-for-gene complementarity in plant-pathogen interactions. Annu. Rev. Genet. 24:447-463.

Keen, N. T., Tamaki, S., Kobayashi, D., and Trollinger, D. 1988. Improved broad-host-range plasmids for DNA cloning in Gram-negative bacteria. Gene 70:191-197.

King, E. O., Ward, M. K., and Raney, D. E. 1954. Two simple media for the demonstration of pyocyanin and fluorescein. J. Lab. Med. 22:301307.

Klement, Z. 1982. Hypersensitivity. Pages 149-177 in: Phytopathogenic Prokaryotes, Vol. 2. M. S. Mount and G. H. Lacy, eds. Academic Press, New York.

Kobayshi, D. Y., Tamaki, S. J., and Keen, N. T. 1989. Cloned avirulence genes from the tomato pathogen Pseudomonas syringae pv. tomato confer cultivar specificity on soybean. Proc. Natl. Acad. Sci. USA 86:157-161.

Leister, R. T., Ausubel, F. M., and Katagiri, F. 1996. Molecular recognition of pathogen attack occurs inside of plant cells in plant disease resistance specified by the Arabidopsis genes RPS2 and RPM1. Proc. Natl. Acad. Sci. USA 93:15497-15502.

Lorang, J. M., and Keen, N. T. 1995. Characterization of avrE from Pseudomonas syringae pv. tomato: A hrp-linked avirulence locus consisting of at least two transcriptional units. Mol. Plant-Microbe Interact. 8:49-57.

Mansfield, J., Jenner, C., Hockenhull, R., Bennett, M. A., and Stewart, R. 1994. Characterization of avrPphE, a gene for cultivar-specific avirulence from Pseudomonas syringae pv. phaseolicola which is physically linked to $\operatorname{hrp} Y$, a new hrp gene identified in the halo-blight 
bacterium. Mol. Plant-Microbe Interact. 7:726-739.

Mindrinos, M., Katagiri, F., Yu, G.-L., and Ausubel, F. M. 1994. The A. thaliana disease resistance gene RPS2 encodes a protein containing a nucleotide-binding site and leucine-rich repeats. Cell 78:1089-1099.

Oliver, D. B., and Beckwith, J. 1981. E. coli mutant pleiotropically defective in the export of secreted proteins. Cell 25:765-772.

Paszty, C., and Lurquin, P. F. 1987. Improved plant protoplast plating/selection technique for quantitation of transformation frequencies. BioTechniques 5:716-718.

Pirhonen, M. U., Lidell, M. C., Rowley, D. L., Lee, S. W., Jin, S., Liang, Y., Silverstone, S., Keen, N. T., and Hutcheson, S. W. 1996. Phenotypic expression of Pseudomonas syringae avr genes in E. coli is linked to the activities of the hrp-encoded secretion system. Mol. Plant-Microbe Interact. 9:252-260.

Preston, G., Huang, H.-C., He, S. Y., and Collmer, A. 1995. The HrpZ proteins of Pseudomonas syringae pvs. syringae, glycinea, and tomato are encoded by an operon containing Yersinia ysc homologs and elicit the hypersensitive response in tomato but not soybean. Mol. Plant-Microbe Interact. 8:717-732.

Rosqvist, R., Hakansson, S., Forsberg, A., and Wolf-Watz, H. 1995. Functional conservation of the secretion and translocation machinery for virulence proteins of yersiniae, salmonellae and shigellae. EMBO J. 14:4187-4195.

Rosqvist, R., Magnusson, K. E., and Wolf-Watz, H. 1994. Target cell contact triggers expression and polarized transfer of Yersinia YopE cytotoxin into mammalian cells. EMBO J. 13:964-972.

Russell, J. A., Roy, M. K., and Sanford, J. C. 1991. Physical trauma and tungsten toxicity reduce the efficiency of biolistic transformation. Plant Physiol. 98:1050-1056.

Sambrook, J., Fritsch, E. F., and Maniatis, T. A. 1989. Molecular Cloning, 2nd ed. Cold Spring Harbor Laboratory, Cold Spring Harbor, NY.

Scofield, S. R., Tobias, C. M., Rathjen, J. P., Chang, J. H., Lavelle, D. T., Michelmore, R. W., and Staskawicz, B. J. 1996. Molecular basis of gene-for-gene specificity in bacterial speck disease of tomato. Science 274:2063-2065.

Silhavy, T., Berman, M. L., and Enquist, L. W. 1984. Experiments with
Gene Fusions. Cold Spring Harbor Laboratory, Cold Spring Harbor, NY. Tang, X., Frederick, R. D., Zhou, J., Halterman, D. A., Jia, Y., and Martin, G. B. 1996. Initiation of plant disease resistance by physical interaction of AvrPto and Pto kinase. Science 274:2060-2062.

Staskawicz, B. J., Dahlbeck, D., and Keen, N. T. 1984. Cloned avirulence gene of Pseudomonas syringae pv. glycinea determines race specific incompatibility on Glycine max (L.) Merr. Proc. Natl. Acad. Sci. USA 81:6024-6028.

Timmermans, M. C. P., Maliga, P., Viera, J., and Messing, J. 1990. The pFF plasmids: Cassettes utilizing CaMV sequences for expression of foreign genes in plants. J. Biotechnol. 14:333-344.

Van den Ackerveken, G., Marois, E., and Bonas, U. 1996. Recognition of the bacterial avirulence protein AvrBs3 occurs inside the host plant cell. Cell 87:1307-1316.

Wattiau, P., Woestyn, S., and Cornelis, G. R. 1996. Customized secretion chaperones in pathogenic bacteria. Mol. Microbiol. 20:255-262.

Wei, Z.-M., Laby, R. J., Zumoff, C. H., Bauer, D. W., He, S. Y., Collmer, A., and Beer, S. V. 1992. Harpin, elicitor of the hypersensitive response produced by the plant pathogen Erwinia amylovora. Science 257:85-88

Willis, D. K., Hrabak, E. M., Lindow, S. E., and Panopoulos, N. J. 1988. Construction and characterization of Pseudomonas syringae recA mutant strains. Mol. Plant-Microbe Interact. 1:80-86.

Xiao, Y., and Hutcheson, S. 1994. A single promoter sequence recognized by a newly identified alternate sigma factor directs expression of pathogenicity and host range determinants in Pseudomonas syringae. J. Bacteriol. 176:3089-3091. Author's correction. 176:6158.

Yahr, T. L., Goranson, J., and Frank, D. W. 1996. Exoenzyme S of Pseudomonas aeruginosa is secreted by a type III pathway. Mol. Microbiol. 22:991-1003.

Yahr, T. L., Hovey, A. K., Kulich, S. M., and Frank, D. W. 1995. Transcriptional analysis of the Pseudomonas aeruginosa exoenzyme S structural gene. J. Bacteriol. 177:1169-1178.

Yanish-Perron, C., Vieira, J., and Messing, J. 1985. Improved M13 phage cloning vectors and host strains: Nucleotide sequences of the M13mp18 and pUC19 vectors. Gene 33:103-119. 